\title{
Lucyna Szaciło
}

Starszy specjalista w Biurze

Logistyki, PKP S.A.

\section{Henryk Zielaskiewicz}

Dyrektor Biura Logistyki PKP S.A.,

Akademia WSB w Dąbrowie

Górniczej

DOI: 10.35117/A_ENG_19_12_02

\section{Development of intermodal transport in the Kujawsko-Pomorskie Region on the example of construction of the intermodal terminal in Emilianowo}

\begin{abstract}
Ones of the most important drivers of the country-wide logistics service performance are the number, quality and functionality of intermodal terminals. A systemic operational cooperation between node elements in the net of such facilities is crucial for the efficiency and environmental friendliness of the national logistic system. Moreover, looking from the perspective of national economy sustainable development, there is also a need to provide intermodal reloading services all over the county so creation of appropriate facilities in regions where they are missing is especially important. The Kujawsko-Pomorskie Region has favourable conditions for placement of logistic service infrastructure. Enterprise strategies should assume increased freight diversification as according to the EU transport policy $30 \%$ of long distance inland surface transport should be done with usage of environmentally friendly modes. Vast majority of freight is transported by roads. Construction of a new railway infrastructure, including intermodal terminals, should create new possibilities in the field of organization of physical distribution flows.
\end{abstract}

Keywords: Intermodal terminal, rail-road; Kujawsko-Pomorskie; Railway BydgoszczEmilianowo

\section{Introduction}

As the economy develops, the demand for various types of logistics services increases. The transport of manufactured products increases year by year. Intermodal units are increasingly used for their transport. In Poland, we observe the dynamic development of freight transport. A number of conditions that have been shaped in recent years mean that road transport is the dominant transport branch. The share of mass transported inland by this branch of transport in 2016 was $87.13 \%$, in 2017 - 87.67\% and in 2018 - 88.00\%. Freight rail transport is developing much more slowly. The share of mass in this market segment is decreasing year by year and was in $2016-12.52 \%$, in $2017-12.04 \%$ and in $2018-11.76 \%$ [2].

The European Union, taking into account the stopping downward trends in the share in the rail transport market, has been promoting the development of intermodal transport through the implementation of various financial support programs for several years. This segment of transport in our country is developing and in the long run, it may contribute to regaining market share for rail transport. For several years there has been an increase in intermodal rail freight transport. In 2018, this transport branch transported 17 million tonnes, in $2017-14.7$ million tonnes, while in 2016 - 12.8 million tonnes [1]. The percentage share of intermodal transport in rail transport in 2017 was $6.12 \%$ in weight and $9.87 \%$ in transport performance, while in $20186.80 \%$ and $10.33 \%$ respectively [6]. 
There are many reasons for the unsustainable development of transport branches in Poland. These include the quality of line and point infrastructure as well as the costs of using it. An important element is also the availability of places for loading goods in the transport process, and therefore even distribution of all types of terminal infrastructure throughout the country. In order to improve the current situation on the freight transport market in terms of increasing the share of rail, coordinated actions are needed between units of various levels of administration and entities involved in the provision of transport services. The network of intermodal terminals in Poland has a strongly differentiated density, which does not cover the entire country. There are regions in which large streams of intermodal loads have developed due to the relatively rapid development of the industry and the accompanying logistics services or at the interface of two transport systems, e.g. seaports and large rail border crossings at track junctions with a clearance of $1520 \mathrm{~mm}$ and $1435 \mathrm{~mm}$. Distinguished areas with significant load streams are: the region of Poznań, Górny Śląsk, Warszawa, Łódź, Wrocław and the largest in terms of cargo streams Terespol-Brześć border crossing, where reloading is carried out in Małaszewicze and Brześć. There are several intermodal terminals in these locations. Other regions have also started to develop economically well with some delay and the level of industrial and logistic urbanization in our country is Kujawskopomorskie province to such regions. There are no intermodal terminals in this area, despite the fact that technological and industrial parks have been created, special economic zones, and transport services are provided by road transport.

\section{Premises for the creation of the intermodal terminal in Emilianów}

Premises for the creation of the intermodal terminal in Placement of the intermodal terminal in Emilianów near Bydgoszcz would enable the service of load flows generated by the Bydgoszcz Industrial and Technological Park and other nearby entrepreneurs in the dynamically developing region. The area of the Kujawsko-pomorskie province, due to the lack of terminal infrastructure, with significant industrial potential, may become a receiving region and at the same time generating containerized load streams. The main assumption for these activities is to achieve positive social effects and economic results of the region, both by the public and private sectors. It should be assumed that the basic condition for sustainable economic growth in the region is the reliability of the functioning of the transport infrastructure adapted to the needs. It should enable connecting individual branches of transport in building efficient transport chains. There are many elements in favour of placing the intermodal terminal in Emilianów, which include:

- dedicated railway line,

- the lower section of the largest river in Poland,

- a large rail and road junction,

- Bydgoszcz Emilianowo station with a well-developed track system,

- cargo airport,

- distance from the functioning network of ports and terminals,

- a large industrial center (formerly Zachem Chemical Plant),

- developed government programs supporting the construction of multimodal terminals, including Strategy for Responsible Development until 2020 (with a perspective up to 2030), Assumptions for plans for the development of inland waterways in Poland for 2016-2020 (with a perspective up to 2030)).

A SWOT analysis was carried out for the project, which indicates the great potential of this location. 


\section{Project description}

Polskie Koleje Państwowe S.A. they own a property in Emilianów near Bydgoszcz with an investment area of approximately 5.6 ha, which they plan to allocate for the construction of an intermodal terminal. The property in question is located approximately $9 \mathrm{~km}$ from the centre of Bydgoszcz and adjoins the city's borders from the south-east and to the areas of the industrial and technology park. The plot runs through the railway line No. 201, the so-called coal main line, which is a state bypass of the Bydgoszcz Agglomeration. Line No. 201 in Bydgoszcz-Maksymilianowo connects to line No. 131 and then branches off towards the Bydgoszcz Wschód station to reconnect with route No. 131 in Nowa Wieś Wielka. This area has access to a public road, i.e. province road No. 274. national road No. 10 runs nearby, and the distance from the A1 motorway is $45 \mathrm{~km}$. Construction of the $\mathrm{S} 10$ express route is planned, in place of the national road No. 10, with the junction in the immediate vicinity of the property. The initial concept of the route involves making collision-free exits to both the areas of the future intermodal terminal and the Industrial and Technological Park (Figure 1).

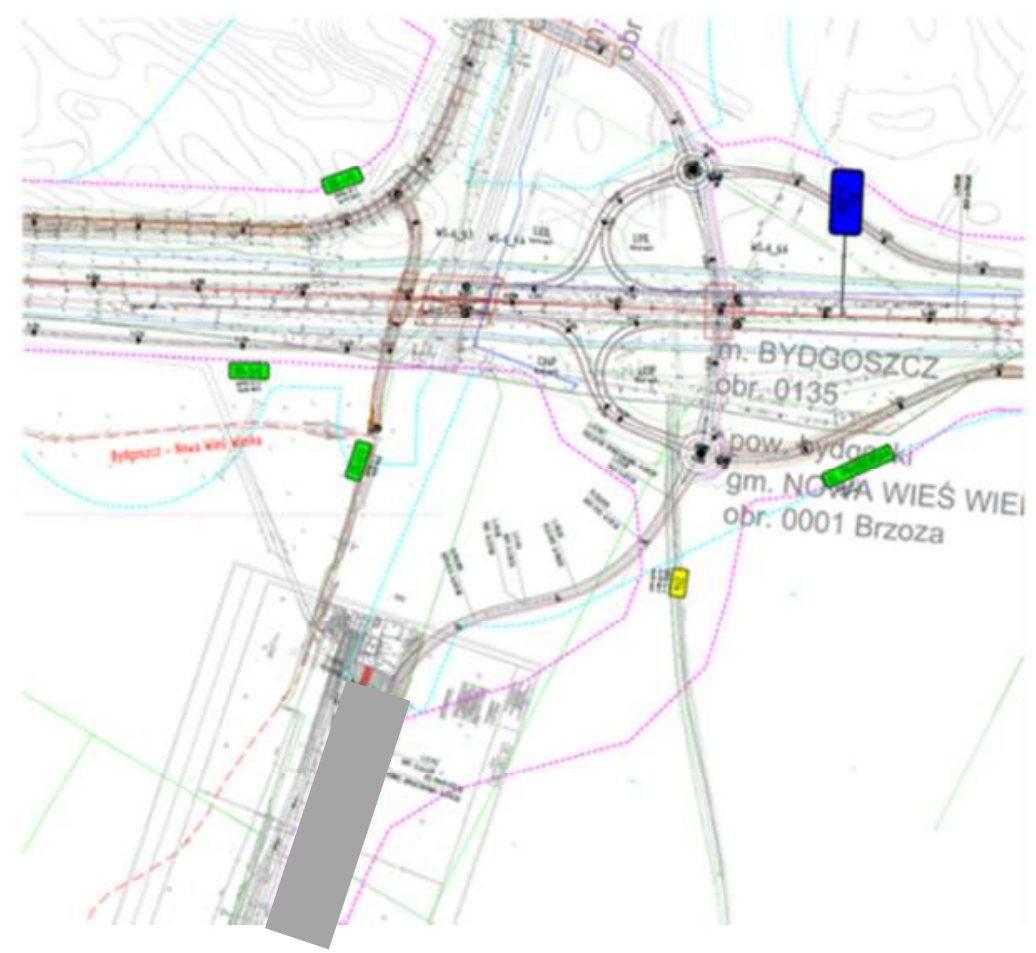

- location of the designed terminal in Emilianów

1. Arrangement of exits from the $S-10$ express road near the planned location of the intermodal terminal in Emilianów adapted to the concept of terminal construction. Source:

GDDKiA.

The intermodal terminal construction project in Emilianów is planned in several stages.

In the first of them, a manoeuvring and storage yard will be built with an area of approx. $15,495 \mathrm{~m}^{2}$ along with drainage of the area - the construction of accompanying infrastructure is planned, among others gas station, transformer station, lighting, fencing, video monitoring, water and sewage, energy and teletechnical networks. The first stage will enable loading and unloading works from track 13 (track closest to the planned storage yard). An access road will be built to the square from the north-east side, allowing exit from national road No. 10 (Circuit Road) in the immediate vicinity of the terminal. 
Tab. 1 Stage I - loading yard along the track No. 13

\begin{tabular}{|c|c|c|c|c|c|c|c|}
\hline \multirow[b]{2}{*}{ Yard } & \multirow[b]{2}{*}{ Type of containers } & \multicolumn{5}{|c|}{ Number of Containers } & \multirow{2}{*}{$\begin{array}{l}\text { The } \\
\text { numer } \\
\text { of TEU }\end{array}$} \\
\hline & & Fields & Ranks & Rows & Layers & Total & \\
\hline \multirow{4}{*}{ Stage I } & 40' (2 TEU) - ordinary & 3 & 1 & 10 & 4 & 120 & 240 \\
\hline & $40^{\prime}$ (2 TEU) - ordinary & 1 & 1 & 2 & 4 & 8 & 16 \\
\hline & $40^{\prime}$ (2 TEU) - dangerous & 1 & 1 & 5 & 4 & 20 & 40 \\
\hline & $40^{\prime}$ (2 TEU) - reefer & 1 & 1 & 2 & 4 & 8 & 16 \\
\hline \multicolumn{6}{|c|}{ Total (Stage I) } & 156 & 312 \\
\hline
\end{tabular}

Source: PKP S.A.

The next stage involves the expansion of the manoeuvring and storage yard to the north by an area of approx. $4,165 \mathrm{~m}^{2}$ along with drainage of the area and construction of accompanying infrastructure, including office and social building, service shelter, lighting, fencing, video monitoring, water and sewage, power and teletechnical networks. Track No. 13 will be built with track support plates so that it is possible to carry out loading and unloading works from track No. 11 with the possibility of entering a transhipment device (second from the storage yard).

Tab. 2 Stage 2 - loading yard along the track No. 13 and storage yard in the area of tracks No. 33 and 35

\begin{tabular}{|c|c|c|c|c|c|c|c|}
\hline \multirow{2}{*}{ Yard } & \multirow{2}{*}{ Type of containers } & \multicolumn{5}{|c|}{ Number of Containers } & \multirow{2}{*}{$\begin{array}{l}\text { The } \\
\text { numer } \\
\text { of TEU }\end{array}$} \\
\hline & & Fields & Ranks & Rows & Layers & Total & \\
\hline \multirow{6}{*}{ Stage II } & 40' (2 TEU) - ordinary & 3 & 1 & 10 & 4 & 120 & 240 \\
\hline & 40' (2 TEU) - ordinary & 1 & 1 & 2 & 4 & 8 & 16 \\
\hline & 40' (2 TEU) - ordinary & 1 & 3 & 9 & 4 & 108 & 216 \\
\hline & $40 '$ (2 TEU) - ordinary & 1 & 3 & 3 & 4 & 36 & 72 \\
\hline & 40 ' (2 TEU) - dangerous & 1 & 1 & 5 & 4 & 20 & 40 \\
\hline & $40^{\prime}$ (2 TEU) - reefer & 1 & 1 & 2 & 4 & 8 & 16 \\
\hline \multicolumn{2}{|c|}{ Total (Stages I and II) } & & & & & 300 & 600 \\
\hline
\end{tabular}

Source: PKP S.A.

In the last stage, the manoeuvring and storage yard will be enlarged by approximately 5,100 $\mathrm{m}^{2}$ along with the addition of accompanying infrastructure on foreign land adjacent to the investment site from the east.

Tab. 3 Stage 3 - loading yard along the track No. 13 and storage yard in the area of tracks No. 33 and 35 extended on foreign land

\begin{tabular}{|c|c|c|c|c|c|c|c|}
\hline \multirow{2}{*}{ Yard } & \multirow{2}{*}{ Type of containers } & \multicolumn{5}{|c|}{ Number of Containers } & \multirow{2}{*}{$\begin{array}{l}\text { The } \\
\text { numer } \\
\text { of TEU }\end{array}$} \\
\hline & & Fields & Ranks & Rows & Layers & Total & \\
\hline \multirow{6}{*}{ Stage III } & 40' (2 TEU) - ordinary & 4 & 3 & 10 & 4 & 480 & 960 \\
\hline & 40' (2 TEU) - ordinary & 1 & 3 & 2 & 4 & 24 & 48 \\
\hline & 40' (2 TEU) - ordinary & 1 & 3 & 9 & 4 & 108 & 216 \\
\hline & 40' (2 TEU) - ordinary & 1 & 3 & 3 & 4 & 36 & 72 \\
\hline & 40' (2 TEU) - dangerous & 1 & 3 & 5 & 4 & 60 & 120 \\
\hline & $40 '$ (2 TEU) - reefer & 1 & 3 & 2 & 4 & 24 & 48 \\
\hline
\end{tabular}


Total (Stages I, II, III)

Source: PKP S.A.

40 'universal containers, 40' refrigerated containers (reefer) and 40 'containers with dangerous goods may be stored on the surface of the terminal board. Containers will be moved between rail transport, road transport and storage yard by means of reach-stacker loading equipment. Before starting the investment, already at the design stage, it is necessary to perform the necessary geological surveys of the soil, dendrological survey, water-legal survey, report on the impact of the investment on the environment, and obtaining a decision on environmental conditions.

By Resolution No. VI / 114/19 of the Sejmik of the Kujawsko-Pomorskie province of May 27, 2019, the Protected Landscape Area of the Dunes of the Kotlina Toruńsko-Bydgoska was designated - eastern and western part. The plans for the construction of an intermodal terminal in Emilianów have been included in the spatial development plan for the KujawskoPomorskie province. In connection with the above, derogations from selected bans included in the Resolution were introduced, which read as follows [3]:

- killing wild animals, destroying their burrows, lairs, other shelters and breeding grounds as well as spawning grounds, complex eggs, with the exception of amateur fishing and performing activities related to rational farming, forestry, fishing and hunting,

- implementation of projects that may significantly affect the environment within the meaning of the provisions of the Act of 3 October 2008 on sharing information on the environment and its protection, public participation in environmental protection and on environmental impact assessments,

- performing earthworks permanently distorting the lay of the land, except for works related to storm, flood or flood protection, or maintenance, construction, reconstruction, repair or renovation of water facilities,

- making changes to water relations, if they serve other purposes than nature protection or sustainable use of agricultural and forestry land as well as rational water or fisheries management.

The Bydgoszcz Emilianowo railway station and the adjacent land were "excluded" from the Protected Area of the dunes of the Kotlina Toruńsko-Bydgoska. 20 ha were excluded in the Bydgoszcz commune, and 125 ha in Nowa Wieś Wielka (Figure 2). 


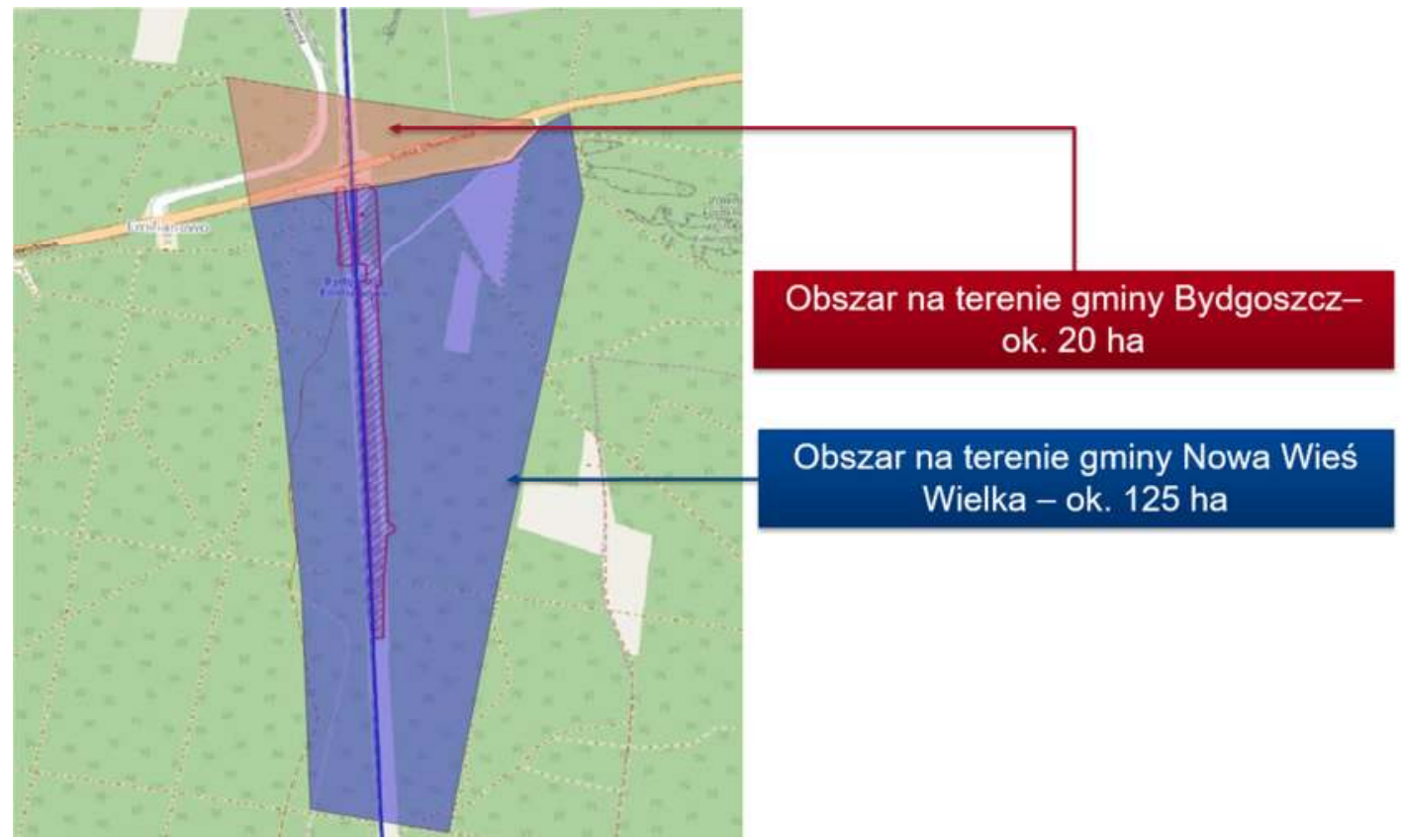

2. Bydgoszcz Emilianowo station in the context of the Dune Conservation Area of the Kotlina Toruńsko-Bydgoska ("off" area), Source: PKP S.A.

\section{Transport conditions in the Kujawsko-Pomorskie province}

According to the data of the Central Statistical Office in the Kujawsko-Pomorskie province, in 2018 the length of railway lines was $1,200 \mathrm{~km}(664 \mathrm{~km}$ single track, $536 \mathrm{~km}$ double track and more). This result represents $6 \%$ of all railway lines in Poland. The electrified railway lines in this area are $563 \mathrm{~km}$, which is less than half the length of all railway lines in the province [2]. Main railway lines No. 201 (Nowa Wieś Wielka - Gdynia Port) and No. 131 (Chorzów Batory-Tczew run through the Kujawsko-Pomorskie province).

Among the railway lines that run through the Kujawsko-Pomorskie province, there can be also mentioned [5]:

1. Primary railway lines:

- No. 18 (Kutno-Piła Główna) double track, electrified,

- No.27 (Nasielsk-Toruń Wschodni), single track, non-electrified,

- No. 353 (Poznań Wschód-Skandawa) double track, electrified,

- No. 208 (Działdowo-Chojnice), single track, non-electrified,

- No. 33 (Kutno-Brodnica) single track, non-electrified,

- No. 734 (Nieszawka-Toruń Towarowy TRB), double track, electrified,

- No. 741 (Mimowola-Jaksice), double track, electrified,

- No. 742 (Inowrocław-Inowrocław Rąbinek), single track, electrified.

2. Secondary railway lines:

- No. 207 (Toruń Wschodni-Malbork), single track, non-electrified,

- No. 281 (Oleśnica-Chojnice), single track, non-electrified,

- No. 206 (Inowrocław Rąbinek-Żnin) single track, non-electrified,

- No. 209 (Kowalewo Pomorskie-Bydgoszcz Wschód), single track, nonelectrified,

- No. 215 (Laskowice Pomorskie-Bąk), single track, non-electrified,

- No. 356 (Poznań Wschód-Bydgoszcz Główna), single track, non-electrified.

3. Railways of local significance:

- No. 231 (Inowrocław Rąbinek-Łojewo), single track, non-electrified,

- No. 245 (Aleksandrów Kujawski-Ciechocinek), single track, electrified, 
- No. 240 (Świecie-Terespol Pomorski), single track, non-electrified,

- No. 241 (Tuchola-Koronowo), single track, non-electrified,

- No. 246 (Toruń Wschodni-Olek), single track, non-electrified,

- No. 736 (Grębocin-Katarzynka), single track, non-electrified,

- No. 745 (Bydgoszcze Główna-Czyżkówko), single track, electrified.

A 5th transport corridor runs through the Kujawsko-Pomorskie province. Railroads Nos. 201 and 131 also lie in the sixth pan-European transport corridor. The target layout of railway transport corridors is shown in figure 3 .

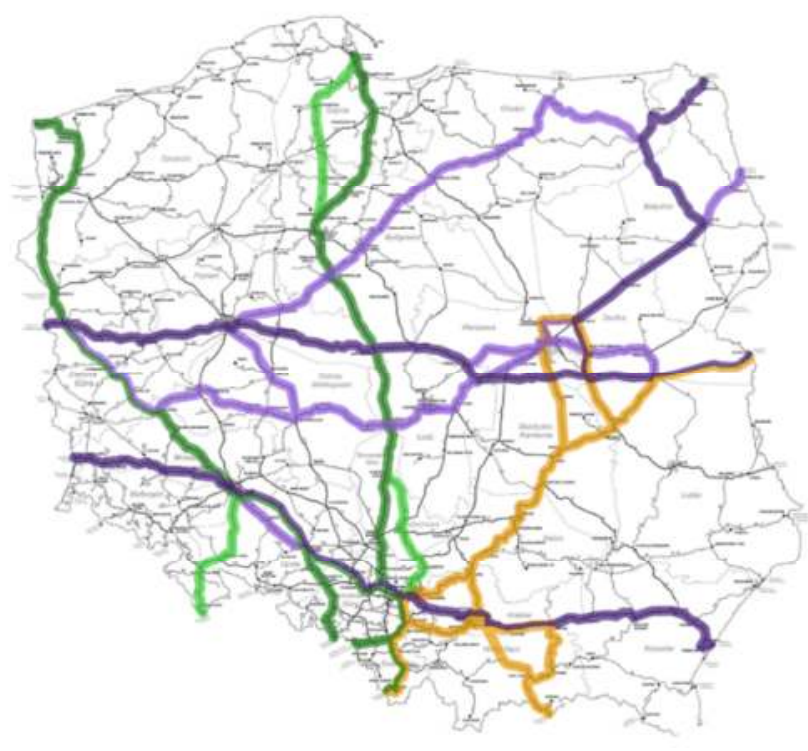

\begin{tabular}{|c|c|}
\hline $\begin{array}{l}\text { - Korytarz } \\
\text { Bałtyckie - } \\
\text { Adriatyckie tras }\end{array}$ & $\begin{array}{l}\text { Morze } \\
\text { Morze } \\
\text { łówna }\end{array}$ \\
\hline $\begin{array}{l}\text { - Korytarz } \\
\text { Bałtyckie - } \\
\text { Adriatyckie } \\
\text { objazdowa }\end{array}$ & $\begin{array}{r}\text { Morze } \\
\text { Morze } \\
\text { trasa }\end{array}$ \\
\hline $\begin{array}{l}\text { - Korytarz } \\
\text { Północne - } \\
\text { Bałtyckie trasa }\end{array}$ & $\begin{array}{l}\text { Morze } \\
\text { Morze } \\
\text { wna }\end{array}$ \\
\hline $\begin{array}{l}\text { - Korytarz } \\
\text { Północne } \\
\text { Bałtyckie } \\
\text { objazdowa }\end{array}$ & $\begin{array}{r}\text { Morze } \\
\text { Morze } \\
\text { trasa }\end{array}$ \\
\hline $\begin{array}{l}\text { - Bursztynowy } \\
\text { Towarowy }\end{array}$ & orytarz \\
\hline
\end{tabular}

3. Planned target arrangement of railway transport corridors, Source: PKP PLK S.A.

In 2018, in the Kujawsko-Pomorskie province, the length of national roads was $1207 \mathrm{~km}$, province - $1751 \mathrm{~km}$, district - $7035.2 \mathrm{~km}$, and municipal roads 17523,2 km. These lengths resulted in a total score of $27516.5 \mathrm{~km}$ (6.5\% of all public roads in Poland) [2].

In the Kujawsko-Pomorskie province, they converge:

- being the axis of the Pan-European Transport Corridor No. VI highway A1 (E75) (Gdańsk-Toruń-Katowice-Gorzyczki - towards: Czech Republic),

- A branch of the transport corridor No. VI, designated as corridor VI A, national road No. 5 (E-261) (Grudziądz-Świecie-Bydgoszcz-Poznań-Wrocław: towards the Czech Republic), leading to corridor No. II.

Among the most important communication routes in the Kujawsko-Pomorskie province should be highlighted:

1. Highway:

- A1 Rusocin - Grudziądz - Toruń - Kutno - Stryków - Łódź - Tuszyn - Piotrków Trybunalski - Kamieńsk - Radomsko - Częstochowa - Pyrzowice - Piekary Śląskie Bytom - Zabrze - Gliwice - Knurów - Rybnik - Żory - Gorzyczki - national border (Czech Republic).

2. Expressways:

- S5 Nowe Marzy - Świecie - Bydgoszcz - Białe Błota - Szubin - Żnin - Gniezno Poznań - Stęszew - Kościan - Śmigiel - Leszno - Rawicz - Żmigród - Prusice Trzebnica - Wrocław, 
- S10 Szczecin - Stargard Szczeciński - Recz - Kalisz Pomorski - Wałcz - Piła Wyrzysk - Pawłówek - Białe Błota - Bydgoszcz - Solec Kujawski - Toruń - Lubicz Dolny - Sierpc - Płońsk - Siedlin.

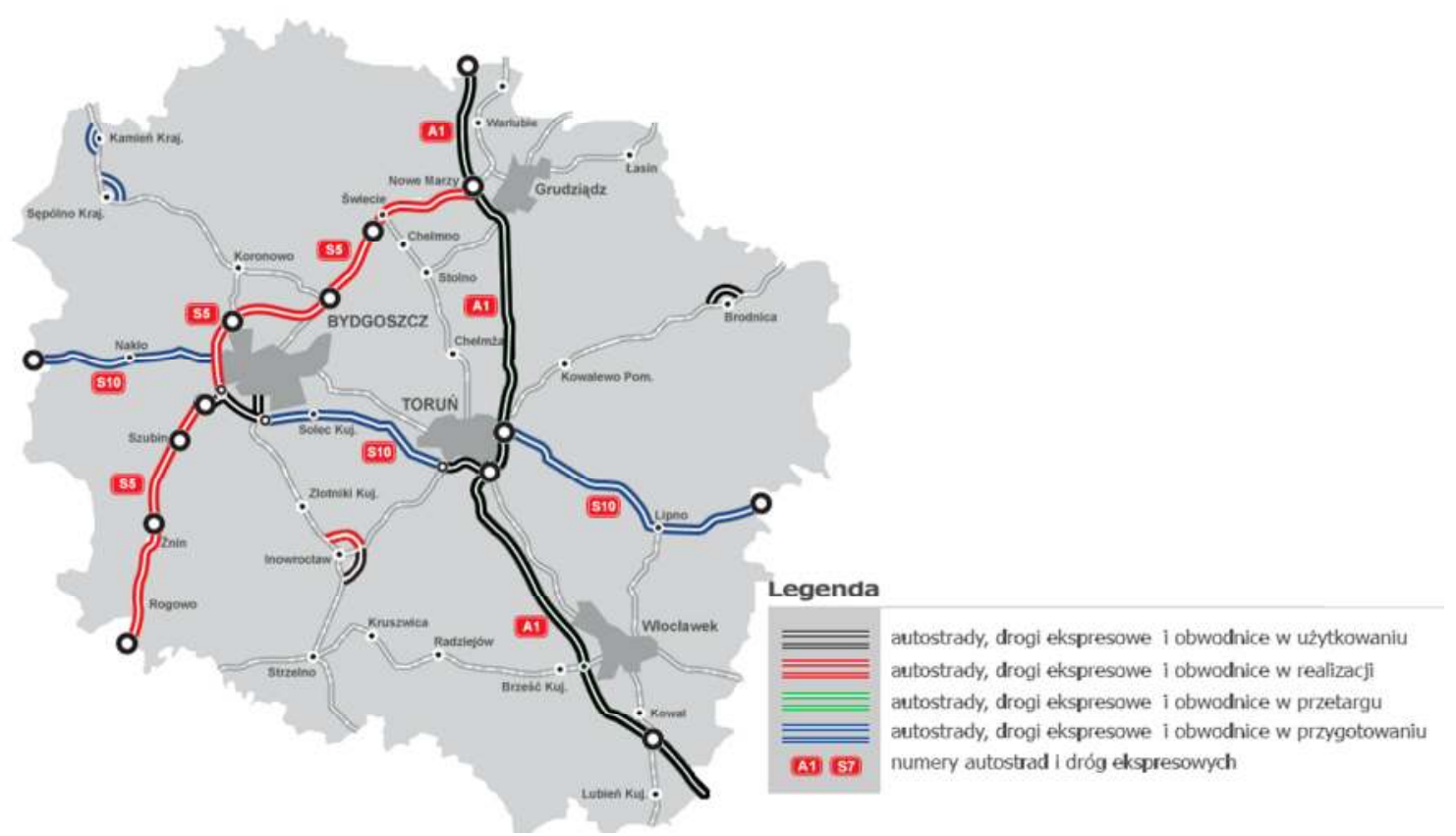

4. Map of the state of road construction in the Kujawsko-Pomorskim province Source: [4]

The intermodal terminal in Emilianów will be located approximately $700 \mathrm{~m}$ from the Bydgoszcz Industrial and Technology Park. This creates the ability to handle cargo flows occur in this area. BPPT covers an area of nearly 287.5 ha, entirely located in the city of Bydgoszcz, in post-industrial area. The area where the Park operates is a place where two types of transport connect: road (national road No. 10) and rail (line 201 runs through the park). BPPT has been in existence since 2003. It is one of the largest parks of this type in Poland. The company brings together over 120 entrepreneurs. Nearly 3,700 people found employment in BPPT. The location of the terminal in Emilianów makes it possible to transfer some of the load streams from the Park to rail transport. The Bydgoszcz Industrial and Technological Park is serviced by road - there are 400 to 600 heavy car sets every day.

In 2018, in the Kujawsko-Pomorskim province, 1,297,724 tonnes of cargo was transported by intermodal car transport, the sixth result in the country. Most cargo with this branch of transport was transported in the Pomorskie province, this is due to the service of seaports in Gdańsk and Gdynia. 


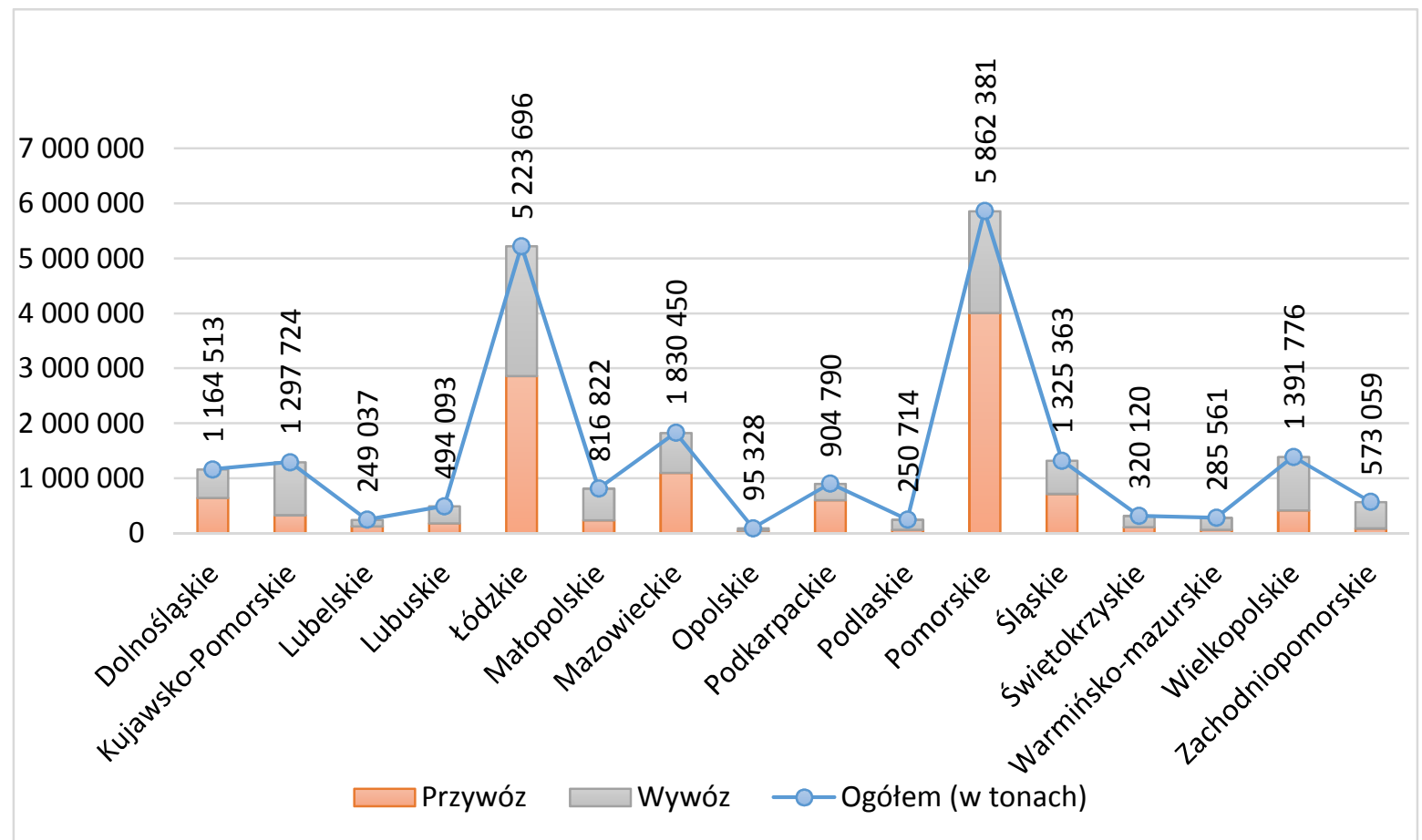

5. Cargo transportation in containers by intermodal road transport by provinces in 2018. Source: Central Statistical Office of Poland.

The geographical location of Poland between Scandinavia and Southern Europe as well as Western Europe and the countries beyond our eastern border is strategic from the point of view of transported goods. Seaports should be seen as an important element of the country's logistics system, whose potential significantly depends on the degree of development of the logistics infrastructure and its quality - both from the sea and land. All types of terminals, including intermodal and line infrastructure, should be the back office enabling the functioning of ports in a network system. This ensures efficient handling of load flows passing through the ports. The effectiveness of logistics operations in the port, including port and rail reloading, is crucial for the proper and appropriate level of handling of intermodal unit shipments. After a period of relative stabilization in the volumes of intermodal vessels transhipped in Polish ports, the last few years have seen high growth dynamics. To maintain these trends, it is necessary to carry out further expansion and modernization of existing infrastructure, both in the ports themselves and inside the country where it is needed.

\section{Conclusions}

A network of publicly accessible terminals should be part of the so-called the Extended Port Gateway, which would allow for organizational changes to be made in the delivery or collection of loading units at land terminals, levelling these operations legally and legally similar to those in seaports. A well-developed transport network with reloading points and other traffic generators connected between various branches of transport is a condition for the implementation of the basic principles of the free flow of goods. Improving the region's transport accessibility will improve the business environment of entrepreneurs trading with domestic and foreign trade partners. A significant improvement in transport accessibility using various modes of transport will be of great importance for choosing the place of settlement for new companies from various industries. One of the objectives of the European Union's transport policy is to accelerate and balance the development of transport and logistics services. In particular, EU legislation is directed at supporting the development of 
intermodal transport, which is seen as the most environmentally friendly real alternative to relatively high-emission road transport along the entire route.

The area of the Kujawsko-Pomorskiego province, due to the lack of terminal infrastructure with the growing potential of the region, meets the criteria for locating the Extended Port Gateway infrastructure.

Construction of the intermodal terminal in Emilianów will be multi-stage and field reserves allow for the creation of new logistics infrastructure facilities. The following annual transhipment capacities are assumed:

Tab. 5. Maximum annual terminal handling capacity in relation to project stages.

\begin{tabular}{|l|l|l|}
\hline Stage & TEU & UTI \\
\hline I & 19900 & 11700 \\
\hline II & 38300 & 22500 \\
\hline III & 88000 & 51700 \\
\hline
\end{tabular}

Source: PKP S.A.

The assumptions of the EU policy and the policy of our state put the investment in Emilianów in a favourable light. Currently, in our country, the emphasis is on increasing the share of rail freight. One of the assumptions of the Strategy for Responsible Development is to start activities aimed at building a supra-regional transport and logistics infrastructure. Emilianowo thanks to its location, i.e. location on the corridor of the TEN-T Baltic-Adriatic network, creates favourable conditions for promoting this project as a supra-regional project.

\section{Source materials}

[1] Sprawozdanie z funkcjonowania rynku transportu kolejowego w 2018 r., Urząd Transportu Kolejowego, Warszawa 2019 r.

[2] Transport - wyniki działalności w 2018 r., Główny Urząd Statystyczny, Warszawa, Szczecin $2019 \mathrm{r}$.

[3] Uchwała nr VI/114/19 Sejmiku Województwa Kujawsko-Pomorskiego z dnia 27 maja 2019 r. w sprawie przyjęcia projektu uchwały w sprawie Obszaru Chronionego Krajobrazu Wydm Kotliny Toruńsko-Bydgoskiej - część wschodnia i zachodnia.

[4] www.gddkia.gov.pl/mapa-stanu-budowy-drog_kujawsko-pomorskie (dostęp 31.10.2019).

[5] www.mapa.plk-sa.pl/9 (dostęp 31.10.2019 r.).

[6] www.utk.gov.pl/pl/raporty-i-analizy/analizy-i-monitoring/statystyka-przewozow-to/danearchiwalne/14817,Przewozy-intermodalne-w-2018-r.html (dostęp 04.11.2019 r.). 